811.163.41'367.625'37

https://doi.org/10.18485/kij.2021.68.1.7

\author{
АНА В. МИЛЕНКОВИЋ ${ }^{*}$ \\ Институт за српски језик САНУ \\ Београд
}

Оригинални научни рад

Примљен: 17.04.2021.

Прихваћен: 26.04.2021.

\title{
ИНТЕНЦИОНАЛНОСТ КАО КРИТЕРИЈУМ КЛАСИФИКАЦИЈЕ ЕМОЦИОНАЛНИХ ГЛАГОЛА У СРПСКОМ ЈЕЗИКУ
}

\begin{abstract}
У раду се анализирају глаголи којима се означава узрочно-последичан процес изазивања емоција или емоционалних промена у другоме. Општа семантичка структура тзв. емоционално-активних глагола (према Миленковић 2015, 2017) подразумева учешће двају актаната: каузатора емоције и доживљавача емоције (односно, носиоца одређеног емоционалног стања). Истраживање је спроведено на корпусу од 242 глагола, а разумевање структуре значења емоционално-активних глагола засновано је на препознавању елемента намере. Анализа грађе показала је да интенционалност није део лексичког значења глагола, већ је њено препознавање условљено сагледавањем ширег ситуационог контекста у којем је глагол употребљен.
\end{abstract}

Кључне речи: емоционални глаголи, каузатор емоције, доживљавач емоције, интенционалност, шира емоционална ситуација, контекстуална условљеност.

\section{1. Увод}

Емоционални глаголи су речи којима се у српском језику означавају емоције, емоционални односи и процеси и шира емоционална ситуација. Њима се осликава однос између онога који осећа и онога што дато осећање у њему изазива. Однос између доживљавача и изазивача емоције постаје сложенији ако се у обзир узму категорије каузалности, интенције, вербалне експресије, понашања, гестикулащије и др. Дати параметри усложњавају глаголску семантику и потврђују да је сам догађај исказан глаголом могуће анализирати из различитих

*ana.milenkovic@isj.sanu.ac.rs

** Овај рад је финансирало Министарство просвете, науке и технолошког развоја Републике Србије према Уговору број 451-03-9/2021-14 који је склопљен са Институтом за српски језик САНУ. 
перспектива, са фокусом на различите аспекте и елементе глаголске радње (Миленковић 2015, 2017).

Емоционалне глаголе којима се означава узрочно-последичан процес изазивања емоције или специфичног емоционалног стања дискутоваћемо у светлу одговора на једно питање: постоји ли намера изазивања емоције у другоме, и ако постоји, да ли је интенциионалност део лексичког значења глагола или се контекстуално препознаје?

\section{2. Интенционалност као филозофско-језичка категорија}

2.1. Термин који је изведен из латинске речи intendere (истаћи, усмерити ка нечему) у вези је са филозофским доктринама Ф. Брентана и Е. Хусерла. У књизи Психологија са емпиријског становишта (1874) Брентано говори о интенциионалности као својству психичких стања и доживљаја да буду усмерени ка нечему (према Анђелковић 2008). Дакле, човек не може само волети, мора волети нешто. Његова психичка делатност мора бити усмерена ка објекту који постоји изван њега самог. Ригидност Брентановог учења огледа се у томе што је сматрао да су сви психички феномени и само психички феномени интенционални, а дата доктрина позната је под називом Брентанова теза (према Мекинтајер/Вудраф Смит 1989: 149). Један од критичара Брентановог поимања интенциионалности био је његов ученик Едмунд Хусерл, који наводи примере психичких стања попут депресије и еуфорије, или сензација попут вртоглавице и бола, који не морају, нужно, бити усмерени на објекат изван доживљавача (према Мекинтајер/Вудраф Смит 1989: 148). Супротно њима, аутор истиче да постоје психички феномени који јесу интенционални, и њих назива делима свести (енгл. acts of consciousness). Њихово основно обележје је обавезно постојање објекта ван доживљавача, односно ентитета на који је одређена психичка делатност усмерена.

2.2. Интенционалност је, по мишљењу Ж. Фоконијеа и М. Тарнера, једна од основних виталних релација нашег ума (Фоконије/Тарнер 2002). Њоме су обухваћене све релације које су у вези са категоријама жеље, наде, хтења, страха, веровања, памћења и сличних психичких активности и стања, која су усмерена на објекат изван доживљавача. Аутори сматрају да је свеукупно понашање човека као бића, заправо, интенционално. Све што човек ради, оно што осећа, о чему размишља, начин на који се понаша - све је утемељено на релацијама које су под окриљем виталне релације интенционалности. Појаве и догађаји који су део човекове стварности могу бити природни (неинтенционални), а могу почивати на намери (интенционални). У том смислу, временске непогоде и природне катастрофе представљају неинтенционалне догађаје, док су све људске активности, у основи својој, интенционалне. Интенционалност, као витална релација, имплицира оно неинтенционално. Сагледавање и прихватање 
човека као интенционалног бића, омогућава разумевање свих начина на које он управља својим емоцијама.

2.3. Из филозофског појма интенционалности изводи се значење датог термина у појмовно-језичкој стварности. Интенционалност подразумева особину човека да спроведе одређену акцију с намером. То је специфично психичко стање усмерености ка одређеном следу догађаја или одређеној ситуацији (према Мекинтајер/Вудраф Смит 1989: 148). О појму намере, у оквирима науке о српском језику, није много дискутовано. Помиње се, најчешће, када се говори о основним елементима шире категорије каузативности (уп. Ивић 1954; Гортан-Премк 1963-1964; Батистић 1978; Ковачевић 1988; Пипер и сар. 2005; Ружин 2015). У том смислу, појам интенщије у вези је са апстрактним концептима као што су жеља, идеја, тежња, ииль, намера и воља.

2.4. Оно што повезује ширу категорију узрока и њој подређену категорију намере јесте појам воље (волунтативности). Намера представља решеност субјекта, његову вољну одлуку да реагује на одређени начин. Та реакција подразумева активност која може бити усмерена ка другоме или ка себи. Намера субјекта обухвата вољу субјекта. Када говоримо о вољи, мислимо, заправо, на аспект виших когнитивних, односно интелектуалних способности човека, што, даље, упућује на чињеницу да је намера повезана са свешћу, односно свесним понашањем, пре свега, људских бића.

\section{3. Предмет и корпус истраживања}

Предмет нашег истраживања у овом раду јесу глаголи којима се у српском језику изражава узрочно-последичан процес изазивања емоције или емоционалне промене у другоме. У питању су тзв. емоционално-активни глаголи (према Миленковић 2015,2017$)$ који подразумевају постојање стимулуса-изазивача и доживљавача емоције. Основно значење емоционално-активних глагола реализује се у два смера: а. изазвати/изазивати емоцију или емоционалну промену $y$ себи (тзв. емоционално-активни глаголи - ка себи) и б. изазвати/изазивати емоцију или емоционалну промену у другоме (тзв. емоционално-активни глаголи - ка другоме). 
Табела 1.

\begin{tabular}{|c|c|c|c|c|}
\hline \multicolumn{5}{|c|}{ ЕМОЦИОНАЛНИ ГЛАГОЛИ } \\
\hline \multicolumn{4}{|c|}{ прави } & експресивни \\
\hline \multicolumn{3}{|c|}{$\begin{array}{c}\text { примарно-емоционални } \\
\text { глаголи }\end{array}$} & \multirow[t]{2}{*}{$\begin{array}{c}\text { секундарно-емоцио- } \\
\text { нални глаголи }\end{array}$} & $\begin{array}{c}\text { глаголи са } \\
\text { значењем } \\
\text { испољавања }\end{array}$ \\
\hline емоц & $\begin{array}{l}\text { ално- } а к- \\
\text { зни }\end{array}$ & $\begin{array}{c}\text { емоцио- } \\
\text { нално-пасивни }\end{array}$ & & \\
\hline $\begin{array}{c}\text { ка } \\
\text { себи }\end{array}$ & $\begin{array}{c}\text { ка } \\
\text { другоме }\end{array}$ & & & \\
\hline
\end{tabular}

Циљ нашег истраживања јесте да предложимо семантичку класификацију дате лексичко-семантичке групе, засноване на критеријуму (не)постојања намере да се процес исказан емоционалним глаголом оствари.

Језичка грађа садржи 242 глагола који су ексцерпирани из Речника српскохрватског књижевног и народног језика САНУ (РСАНУ) ${ }^{1}$ и Речника српскохрватскога књижевног језика Матице Српске I-VI (РМС): анимирати, блажити, блажити се, бодрити, бодрити се, бринути, веселити, вређати, гадити, гадити се, ганути, гневити, грозити, деморалисати, депримирати, догрдети, дозлогрдити, допадати се, допасти се, досадити, жалостити, жестити, забавити, забављати, забезекнути, забринути, забриьавати, завадити, завести, заводити, задивити, задовољити, замахнитати, замерати се, замерити се, запағити, заплакати, заплашити, запрепастити, зарадовати, засмејавати, засмејати, засралити, застидети, застравити, застрашити, затиштати, зачудити, згадити, згадити се, згражати, згранути, зграғавати, згрозити, зловољити, злостављати, избезумити, изљутити, измучити, изненадити, изнервирати, импресионирати, индигнирати, инспирисати, интересовати, иритирати, испрепадати, испровоцирати, једити, јуначити, киьити, корити се, кудити се, куражити, куражити се, љутити, милити, милити се, мразити, мразити се, мучити, наједити, најежити, наљутити, намритити, напатити, насекирати, насмејати, нежити, нервирати, обвеселити, обвесељавати, обеспокојавати, обеспокојити, обесхрабривати, обесхрабрити, ободрити, ободрити се, обрадовати, овеселити, овесељавати, огадити, огадити се, огорчавати се, огорчити се, одобровољити, одушевити, одушевљавати, ожалостити, ожалошћивати, озловољити, озлоједити, озлојеђивати, ојадити, ојађивати, окуражавати, окуражавати се, окуражити, омалодушити, омилити, омилити се, омразити, омразити се, омразити се, омрзнути, омрзнути, омрзнути се, онеспокојити,

\footnotetext{
${ }^{1}$ Ексцерпирани су глаголи из 21 објављеног тома (I-XXI).
} 
орасположити, осоколити, охрабривати, охрабривати се, охрабрити, очаравати, очарати, плашити, побеснити, поколебати, покуғити, помамити, помамљивати, помахнитати, помразити, поплашити, посвађати, посвађати се, постидити, потешити, потиштити, поублажавати, поублажити, поумирити, поутешити, прекорити се, пренеразити, препадати, препасти, преплаиити, престравити, престрављивати, притешити, прогневити, радовати, ражалостити, ражестити, разбеснети, развеселити, развесељавати, разгалити, разгневити, разгоропадити, раздрагати, раздраживати, раздражити, разјадити, разјарити, разједити, разљутити, разнежити, разочаравати, разочарати, раскуражити, раскуражити се, расплакати, расположити, распомамити, распомамљивати, расрдити, растужити, расивелити, револтирати, свидети се, свиђати се, секирати, смиловати, смилостивити, смразити, смучити се, сневеселити, сневесељавати, снуждити, соколити, сплашити, срдити, срећити, стравити, страшити, тешити, тешити се, тиштати, увеселити, увесељавати, удобровољити, ужасавати, ужаснути, узбудити, узбуђивати, узбунити, узбунивати, узбуркавати, узбуркати, узнемиравати, узнемирити, узрујавати, узрујати, умилостивити, умиривати се, умирити, унеспокојити, унесрећити, уплашити, усплахирити, усрећити, устравити, устрашити, усхитити, утешити, уцвелити, храбрити, храбрити се, чудити и шокирати. ${ }^{2}$

\section{4. Предлог класификације емоционално-активних глагола (према критеријуму интенционалности)}

4.1. Емоционално-активни глаголи - ка себи. Од укупног броја глагола који чине нашу језичку грађу, мало је оних којима се означава емоционални процес у којем је субјекат истовремено и изазивач и доживљавач емоције. У питању су прави повратни глаголи који означавају радњу коју субјекат врши на себи, као објекту (према Стевановић 1969: 533-538). Таквих глагола је укупно 13 (блажити се, тешити се, умиривати се, бодрити се, куражити се, ободрити се, окуражавати се, охрабривати се, раскуражити се, храбрити се, корити се, кудити се и прекорити се).

\footnotetext{
${ }^{2}$ У раду се рефлексивна и нерефлексивна форма глагола посматрају као засебне лексеме.

${ }^{3}$ У истраживању су прави повратни и узајамно повратни глаголи посматрани одвојено.
} 


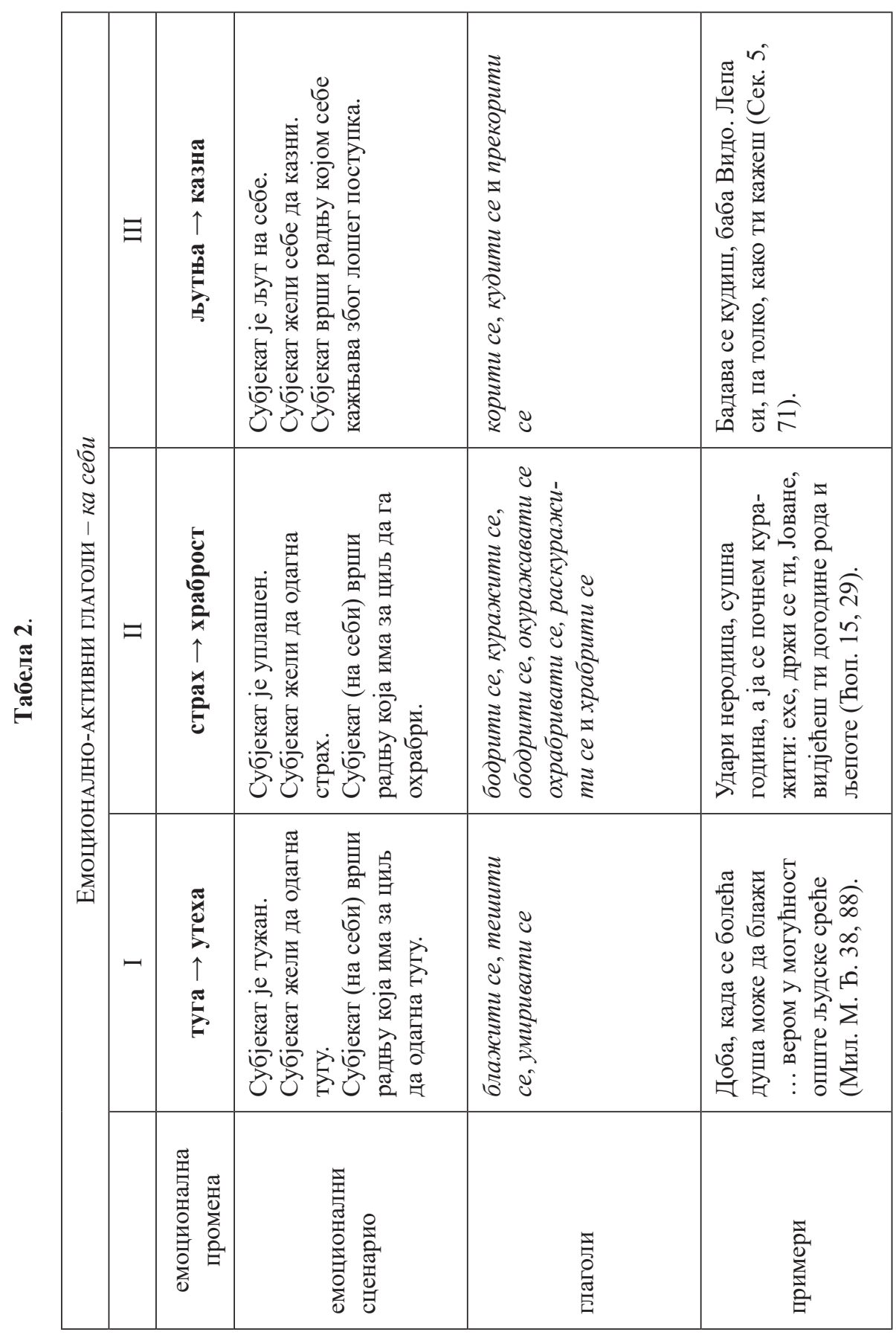


Емоционално-активним глаголима - ка себи изражавају се емоционалне промене које се дешавају у самом субјекту. Реченични субјекат је истовремено доживљавач емоције и каузатор емоционалне промене. Глаголом је означен процес у којем субјекат, својом свесном акцијом, трансформише непријатну емоцију у емоционално стање које припада опсегу пријатности. Свака емоционална промена може се приказати у форми емоционалног сценарија. Он обухвата иницијално емоционално стање субјекта (нпр. тугу), вољу да се дата непријатна емоција отклони и делање које је усмерено ка том циљу. Други сценарио подразумева трансформацију љутње у одређени облик самодеструкције (кажњавања, замерања себи).

4.2. Емоционално-активни глаголи - ка другоме. Другу групу глагола чине они којима се означава процес изазивања емоције или емоционалне промене у другоме. Наша језичка грађа обухвата 229 таквих глагола, које смо груписали према критеријуму (не)постојања намере да се у другоме изазове одређена емоционална промена. Будући да узроковање емоције може бити свесно (с намером) или несвесно (без намере), глаголе смо поделили на: а. праве неинтенционалне емоционално-активне глаголе (нпр. гадити се некоме, свиђати се некоме, доcaдити некоме и сл.) и б. емоционално-активне глаголе код којих је интенционалност контекстуално условљена, тј. исти глагол може имати и интенционално и неинтенционално значење (нпр. љутити, разбеснети, узбуђивати, веселити некога и др.).

4.2.1. Прави неинтенционални емоционално-активни глаголи. У нашој грађи препознали смо 18 глагола којима се означава узрочно-последичан процес у којем субјекат, без намере (дакле, несвесно), у другоме изазива одређену емоцију или утиче на промену његовог емоционалног стања. У емоционалном догађају учествују два актанта, синтаксички изражени логичким и граматичким субјектом, при чему се логички субјекат увек јавља у облику датива без предлога и има семантичку улогу доживљавача емоције. ${ }^{4}$ Стимулус изазивач, означен граматичким субјектом, није свестан свог утицаја на доживљавача.

\footnotetext{
${ }^{4} \mathrm{У}$ својој докторској дисертацији под називом Дативне рекцијске конструкције са непрелазним глаголима у савременом српском језику Б. Стипчевић говори о тзв. дативу доживљавача и глаголима типа допасти се, свиђати се, досадити и (о)гадити се (Стипчевић 2014: 199-220).
} 
Табела 3.

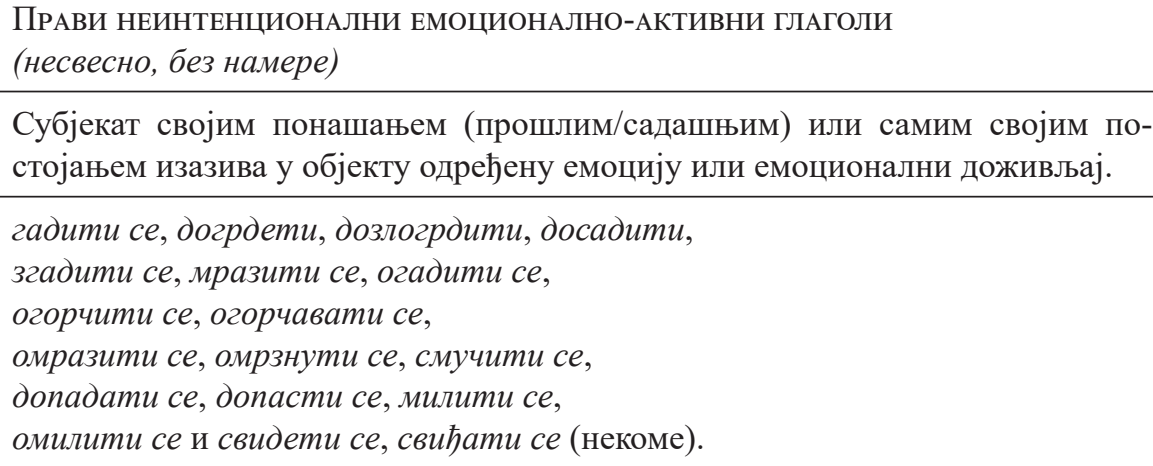

И кад год сам погледо на вас гадили сте ми се, и моро сам да вас презирем (Косор 4, 152).

Народ је много претрпео муке и зла, али му ово догрди (Мил. М. Ђ. 17, 57).

Већ му било дозлогрдило понашање неврједна синовца (Кум. 1, 79).

Кад познадох какав је циник, онда ми се згади (Мат. 11, 25).

Младићу је брзо досадио рат, огадила му се грубост (Селим. 3,238$){ }^{5}$

Не допадају ми се такова дјеца (Прер. П. 2, 102).

Знаш, да си лијепа и да се другима милиш (Цар Ем. 2, 82).

Ако ти се ниједна [девојка] не свиди, ти реци (Весел., РМС).

Неинтенционалним емоционалним глаголима означава се узроковање емоционалног доживљаја субјекта (израженог логичким субјектом) у вези са стимулусом-изазивачем (израженог граматичким субјектом) или неким другим објектом (особом, предметом, догађајем, појавом и сл.) који постоји изван њега. У питању је емоционални доживљај, будући да код стимулуса изазивача не постоји намера да делује на доживљавача, што даље значи да је процена емоционалног догађаја искључиво у вези са субјективним доживљајем онога ко осећа и начином на који ће одређену ситуацију емоционално проценити. Дожсвљавач је увек људско биће, док каузатор емоције може бити човек или одређени конкретан/апстрактан објекат. Доживљавач процењује понашање, активност, изглед или значење стимулуса-изазивача и на основу своје процене ствара одређени доживљај.

4.2.2. Емоционално-активни глаголи - са и без намере (контекстуално условљена интенционалност). Највећи део наше језичке грађе чини 211 емоционалних глагола, који могу остварити интенциионално или неинтенционално емоционално значење, а оно се препознаје на основу ширег језичког контекста, односно свеукупне емоционалне ситуације описане глаголом.

${ }^{5}$ Као што ћемо видети у наставку текста, стимулус-изазивач може бити, осим човека, и одређени конкретан или апстрактан објекат. 


\title{
Табела 4.
}

\author{
КОНТЕКСТУАЛНО УСЛОВЉЕНА ЕМОЦИОНАЛНОСТ \\ ( $с а$ и без намере)
}

Субјекат својим понашањем (с намером или не) изазива у другоме (доживљавачу) емоцију или емоционално стање.

бринути, изнервирати, плашити, насмејати, радовати, усрећити и др.

Брине ме много њена болест! (Нуш. 3, 275).

Нека никога не брине брига да се има о чему писати (Весел. 19, 281).

Знао [је] да ће га чекање у „реду” још више изнервирати (Комар. 1, 8).

Ово пројахивање [коња пре скакања] треба да загреје и умири коња, а не да га умори и изнервира (Преп. јах., 29).

Плаше ме ове лепоте јануарске, јер се бојим да их у априлу и мају не искијамо (Весел., РМС).

Она ме већ одавна плаши учитељем (Павич. 2, РМС).

Нико као они није умео тако да развесели и насмеје друштво (Срем. 15, 94).

фиг. Помоли се иза црногорских висова сунце и насмије крај (Вил. 3, 263).

Рекао ми брале да ти не кажем одмах. „Хоћу, вели, да обрадујем нану ...” - О, Бог ми га обрадовао! (Глиш. 6, 229).

Сине, жив ми и срећан био! Нека те Бог развесели и обрадује! (Весел. 7, 133). Вијест је канда и њега обрадовала, јер се одмах пожурио у порту (Павич. 2, 176).

Све што сам радила ... било је да усрећим и утешим своју мајку (Уск. 2, РМС).

Људи ... мисле да их је злато кадро усрећити (Крешић С., РМС).

Контекстуално условљени емоционално-активни глаголи означавају два типа емоционалне ситуације: а. ону у којој постоји намера да се изазове емоција у другоме и б. ону у којој намера не постоји, већ је у питању лични, субјективни доживљај. Када имају интенционално значење, датим глаголима се означава свестан, намеран узрочно-последичан процес изазивања емоције или промене емоционалног стања доживљавача (објекат) од стране стимулуса-изазивача (субјекат). Када имају неинтенционално значење, дати глаголи једнаки су правим неинтенционалним емоционално-активним глаголима. Наведени примери показују да је постојање намере контекстуално условљено, односно да није део лексичког значења глагола. Саิм глагол не открива постојање, односно непостојање намере да се утиче на другога. Међутим, у њему се и даље препознаје основно својство емоционално-активних глагола, а то је да означавају процес узроковања емоције, због чега закључујемо да је каузативност обавезни део њиховог лексичког значења. 


\section{5. Закључна разматрања}

Емоционално-активни глаголи означавају узрочно-последичан процес у којем је субјекат каузатор емоције, док улогу доживљавача имају граматички субјекат (емоционално-активни глагол - ка себи) или објекат/логички субјекат (емоционално-активни глагол - ка другоме). У зависности од тога да ли се узроковање емоције реализује са или без намере, емоционално-активне глаголе усмерене ка другоме поделили смо на интенционалне и неинтенционалне.

Мали је број глагола који су неинтенционални, тј. оних којима се означава несвесно изазивање осећања у другоме (нпр. Мара се допада Петру или Мара се згадила Петру). Сви остали емоционално-активни глаголи имају контекстуално условљену интенционалност, што значи да се једино на основу ширег ситуационог контекста може установити о каквом је узроковању реч: Мара је иритирала Петра (несвесно, на пример својим облачењем, смехом, говором и сл.) или Мара је гребала ноктима по табли и иритирала Петра (свесно, с намером да у њему изазове непријатну емоцију).

Узимајући у обзир компоненту интенционалности, емоционално-активне глаголе поделили смо на два типа:

I. Прву групу чине глаголи којима се означава неинтенщионално изазивање емоције. Код датих глагола каузатор (изражен граматичким субјектом) нема намеру да у доживљавачу (израженог логичким субјектом) изазове емоцију или промену емоционалног стања. У фокусу значења неинтенционалних глагола је, заправо, субјективан, лични доживљај онога ко осећа (у реченици изражен логичким субјектом). Дакле, исто је ако кажемо Мара се згадила Петру и Ручак се згадио Петру, јер ни код Маре ни код ручка не постоји намера да изазову гађење. Да је у питању лични доживљај потврђујемо чињеницом да ни Мара ни ручак не морају, код друге особе, изазвати осећај гађења.

II. Код већег броја емоционално-активних глагола препознајемо тзв. контекстуално-условљену интенционалност. Рекли смо да структура емоционално-активног глагола подразумева постојање каузатора и доживљавача емоције. Природа каузатора је двојака: дату улогу могу имати ентитети који припадају аниматној (човек) и неаниматној (предмет, идеја, појава и сл.) реалности. Погледајмо следеће примере:

Мара је бодрила Петра.

Петра је бодрило слушање химне.

У оба примера употребљен је глагол - бодрити. Разлика у њиховим значењима условљена је обележјем аниматности/неаниматности каузатора емоције. У првом примеру каузатор је човек, док је у другом примеру каузатор песма (химна). Као што видимо, у другом примеру не постоји намера, због чега се значење глагола може сматрати неинтенционалним. Дакле, у реченицама у којима семантичку улогу каузатора емоције има неаниматни ентитет, глаголско 
значење увек је неинтенционално. Када се у улози каузатора појављује човек, за одређивање глагола као интенционалног или неинтенционалног, неопходан је шири ситуациони контекст. Ако се вратимо на претходни пример - Мара је бодрила Петра, не можемо тврдити да се акција субјекта изводи с намером. Због тога прибегавамо разумевању шире емоционалне ситуације:

Мара је (речима подршке) бодрила Петра.

Мара је (самим својим присуством) бодрила Петра.

Фоконије и Тарнер сматрали су да је човек, типично, интенщионално биће (Фоконије/Тарнер 2002). Све његове активности увек су усмерене ка некоме или нечему. Усмереност је, по природи својој, интенционална. Ако у складу са датим мишљењем протумачимо наше емоционално-активне глаголе, рећи ћемо да је њихово значење, типично, интенциионално. У том смислу, значење емоционално-активног глагола, без ширег ситуационог контекста, сматраћемо априори интенционалним.

На плану полисемије и развоја нових глаголских значења, претпостављамо да се из типичних интенционалних ситуација развијају неинтенционалне. На пример, глагол заводити некога јесте типичан интенционални глагол, којим се исказује типична емоционална ситуација у којој су актери особе, при чему једна има улогу каузатора, а друга улогу доживљавача - Мара заводи Петра. Међутим, типична интенционалност глагола заводити, променом стимулуса-изазивача емоције, трансформише се у неинтенционалност, коју препознајемо у примеру - Завеле су га нове идеологије.

И, на крају, намера је карактеристика агенса, онога ко у одређеној ситуацији има улогу изазивача емоције. У питању је специфично стање субјекта, које га усмерава на одређену акцију или понашање. У том смислу, можемо говорити о међуодносу субјекта-намере-акције, јер без постојања намере (односно, циља), нема ни реализације емоционалне акције од стране субјекта (каузатора).

\section{ЛИТЕРАТУРА}

Анђелковић 2008: М. Анђелковић, Интенционалност и континуитет свести - Брентано и Џејмс, THEORIA 3, 15-27.

Батистић 1978: Т. Батистић, О неким аспектима анализе каузативних глагола, Јужнословенски филолог XXXIV, 59-89, Београд.

Гортан-Премк 1963-1964: Д. Гортан-Премк, Падежне и предлошко-падежне узрочне конструкције код Вука, Јужнословенски филолог XXVI, 437-457.

Ивић 1954: М. Ивић, Узрочне конструкције с предлозима ЗБОГ, ОД, ИЗ у савременом књижевном језику, Наш језик V/5-6, 186-194. 
Ковачевић 1988: М. Kovačević, Uzročno semantičko polje, Sarajevo: Svjetlost, biblioteka „Lingvistika-Poetika”.

Мекинтајер/Вудраф Смит 1989: R. McIntyre, D. Woodruff Smith, Theory of Intentionality, in: J. N. Mohanty and William R. McKenna (eds.), Husserl's Phenomenology: A Textbook, Center for Advanced Research in Phenomenology and University Press of America, Washington D.C., pp. 147-179.

Миленковић 2015: А. Миленковић, Семантичке улоге доживљавача и изазивача емоције у значењској структури емоционалних глагола у српском језику, Наш језик XLVI /3-4, 23-38.

Миленковић 2017: А. Миленковић, Семантичка и творбена анализа глагола којима се означавају осећања у савременом српском језику, докторска дисертација.

Пипер 2005: П. Пипер, Семантичке категорије у простој реченици: синтаксичка семантика, у: Пипер и сар. 2005: 575-982.

Пипер и сар. 2005: П. Пипер, И. Антонић, В. Ружић, С. Танасић, Љ. Поповић, Б. Тошовић, Синтакса савременога српског језика (проста реченица), Београд - Нови Сад: Институт за српски језик САНУ - Матица српска.

Стевановић 1969: М. Стевановић, Савремени српскохрватски језик (граматички системи и књижевнојезичка норма) II. Синтакса, Научна књига, Београд.

Стипчевић 2014: Б. Стипчевић, Дативне рекиијске конструкиије с непрелазним глаголима у савременом српском језику, Необјављена докторска дисертација одбрањена на Филолошком факултету, Универзитета у Београду.

Ружин 2015: Т. Ружин, Глаголи узроковања у енглеском и српском језику, Необјављена докторска дисертација одбрањена на Филолошком факултету, Универзитета у Београду.

Фоконије-Тарнер 2002: G. Fauconnier, M. Turner, The way we think. Conceptual blending and the Mind's hidden complexities, Basic Books, New York.

\section{ИЗВОРИ}

РСАНУ: Речник српскохрватског књижевног и народног језика, 1-20, Београд: Српска академија наука и уметности, 1959- .

PМC: Речник српскохрватскога књижевног језика, 1-6, Нови Сад - Загреб: Матица српска - Матица хрватска, 1967-1976. 
Ana V. Milenković

\title{
INTENTIONALITY AS A CRITERIA FOR THE CLASSIFICATION OF EMOTION VERBS IN THE SERBIAN LANGUAGE
}

\begin{abstract}
Summary
The paper analyzes verbs which denote the process of causing emotions or emotional changes in others. The semantic structure of emotionally-active verbs (according to Milenković 2015, 2017) implies the participation of two actants: the causative stimulus (the provoker of the emotion) and the experiencer of emotion (that is, the bearer of a certain emotional state). The research was conducted on a corpus of 242 verbs, whereas the understanding of the meaning structure of emotionally-active verbs was based on recognizing the intention to provoke a certain emotion in another person or to influence a change in his emotional state. The analysis of the material showed that intentionality is not a part of the verb's lexical meaning, and that its recognition is conditioned by the understanding of the broader situational context in which the verb is used.
\end{abstract}

Key words: verbs of emotion, the causative stimulus, the experiencer, intentionality, the emotional situation, contextual conditioning. 